\title{
Collaboration in Implementation of Bantuan Stimulan Perumahan Swadaya Pontianak City
}

\author{
Verdico Arief \\ D-IV Public Administration Study Programme Pontianak State Polytechnic
}

\begin{abstract}
Bantuan Stimulan Perumahan Swadaya masyarakat (BSPS) is a government provided assistance to help renovate uninhabitable homes for low income communities. Pontianak City Government has implemented this program since several years ago. But in the implementation there is still a problem, the cause of problem is because in implementing this activity involves many parties who have different perception and create discretion in different decision making thereby impeding the implementation of program. It causes the implementation of program to be inhibited. For that it's interesting if conducted a study to examine how collaboration in implementation of Bantuan Stimulan Perumahan Swadaya Pontianak City. Research was conducted qualitatively with descriptive approach using case study technique, using the collaborative theory proposed by Russell M. Linden. From the results of this research will be obtained solution of the problems and collaboration model.
\end{abstract}

Keyword: Collaboration, Bantuan Stimulan Perumahan Swadaya (BSPS), Pontianak.

\section{Research Backgound}

Pontianak City is the Capital City of Kalimantan Barat Province. Pontianak City has an area about $107.82 \mathrm{~km} 2$, where the area is occupied by approximately 655.8572 inhabitants. Pontianak City has 6 districts and divided into 29 sub-districts, 534 hamlet and 2,372 neighborhoods. Geographically, Pontianak City is in the Kapuas River Estuary. Pontianak city is inhabited by various types, which are dominated by Melayu, Dayak, and Tionghoa. People's life in Pontianak City is currently secure and conducive, inversely proportional to what happened to the condition of the city a few decades ago. The key to the success of the society which consists of various kinds of people living in the Pontianak City is because the Government has managed the social order of the nation and state well. This can be done by making policies or programs that favor the population fairly and equally. One of the things that was made and implemented by the Pontianak City Government was Bantuan Stimulan Perumahan Swadaya.

Bantuan Stimulan Perumahan Swadaya is a home renovation assistance for low-income society who have an unhabitable house. This assistance was provided by the Pontianak City Government. The aim is to increase the initiative of low-income society in the development/ improvement of the quality of houses and their infrastructure, facilities and utilities. The purpose of Bantuan Stimulan Perumahan Swadaya activity is to build livable houses by low-income society supported by infrastructure, facilities and public utilities so as to make healthy, safe, harmonious and regular also sustainable housing, which has been regulated in Peraturan Menteri Pekerjaan Umum dan Perumahan Rakyat Republik Indonesia Nomor 13/PRT/M/2016 tentang Bantuan Stimulan Perumahan Swadaya, Undangundang Nomor 1 Tahun 2011 tentang Perumahan Rakyat dan Kawasan Permukiman pasal 5 ayat (1), "Negara bertanggung jawab atas penyelenggaraan perumahan dan kawasan permukiman yang pembinaannya dilaksanakan oleh pemerintah" and pasal 54 ayat (1), "Pemerintah wajib memenuhi kebutuhan rumah bagi Masyarakat Berpenghasilan Rendah (MBR). One of them is awarding of Bantuan Stimulan Perumahan Swadaya.

Bantuan Stimulan Perumahan Swadaya (BSPS) is given to low-income society by involving several institutions or groups. These institutions or parties include Dinas Pekerjaan Umum dan Perumahan Rakyat of Pontianak City, independent facilitators, and types of companies engaged in 
construction materials. These three elements collaborate with each other to carry out Bantuan Stimulan Perumahan Swadaya in Pontianak City.

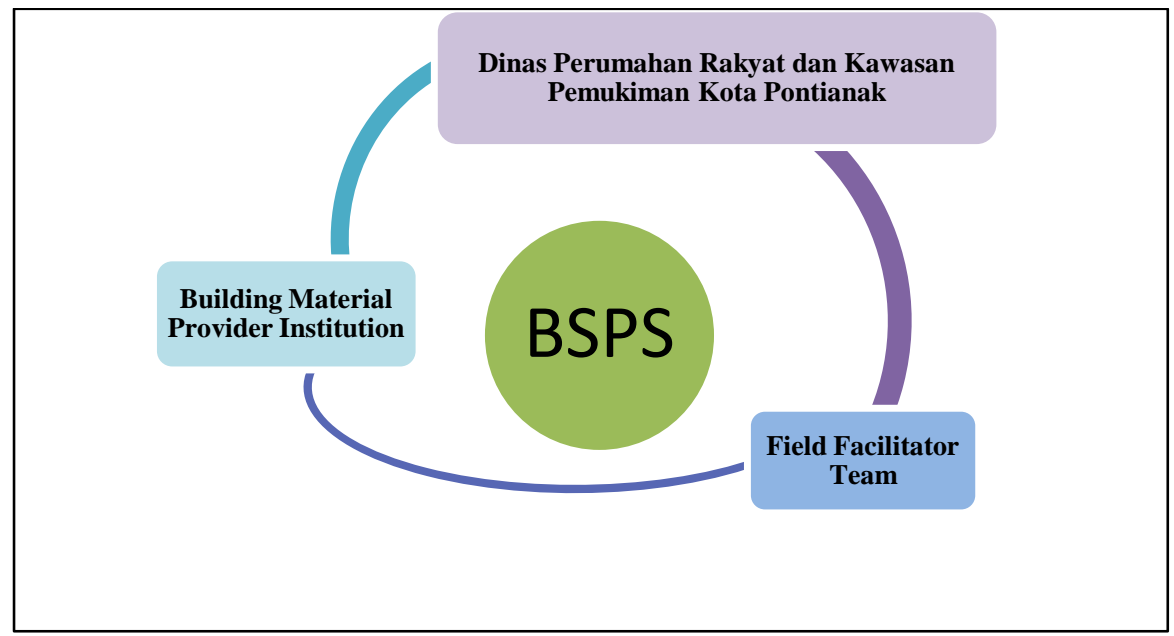

Source: Researcher, 2017

Picture 1. Collaborative Illustration of Bantuan Stimulan Perumahan Swadaya Program

This program is focused on several districts in Pontianak City which have the most number of uninhabitable houses among other districts and that are districts considered slum. This is in line with the Central Government which calls for this assistance to be prioritized to solve the problem of slums. Referring to this in 2017, the Pontianak City Government provided Bantuan Stimulan Perumahan Swadaya Program to a number of districts which were considered the most feasible to obtain such assistance. The districts include West Pontianak district, East Pontianak district, and North Pontianak district. In 2017, the Pontianak City Government allocated approximately Rp. 8,220,000,000, - to carry out Bantuan Stimulan Perumahan Swadaya activitiy intended for 548 units of uninhabitable housing in the City of Pontianak at several different district points.

\begin{tabular}{|c|c|c|c|c|c|c|c|}
\hline & \multicolumn{8}{|c|}{ District in Pontianak City } \\
\cline { 2 - 8 } & $\begin{array}{c}\text { Pontianak } \\
\text { Barat }\end{array}$ & $\begin{array}{c}\text { Pontianak } \\
\text { Kota }\end{array}$ & $\begin{array}{c}\text { Pontianak } \\
\text { Selatan }\end{array}$ & $\begin{array}{c}\text { Pontianak } \\
\text { Tenggara }\end{array}$ & $\begin{array}{c}\text { Pontianak } \\
\text { Timur }\end{array}$ & $\begin{array}{c}\text { Pontianak } \\
\text { Utara }\end{array}$ & Total \\
\hline RTLH & 442 & 188 & 109 & 88 & 695 & 518 & 2040 \\
\hline BSPS & 153 & 0 & 0 & 0 & 349 & 46 & 548 \\
\hline
\end{tabular}

Source: Dinas Perumahan Rakyat dan Kawasan Permukiman of Pontianak City, 2017

Tabel 1. Data on Number of Rumah Tidak Layak Huni (RTLH) and Bantuan Stimulan Perumahan Swadaya (BSPS) in Pontianak City 2017

In the implementation of the cooperation established by several parties in implementing Bantuan Stimulan Perumahan Swadaya throughout 2017 indicates something that has not been maximized. This is reflected in the ongoing renovation of people's homes that are not in accordance with the specimen. Every people who eligible to get Bantuan Stimulan Perumahan Swadaya is provided with material assistance of 15 million rupiah to renovate their house. The only renovation allowed is to do renovations on the front side of the house, but there are some people and facilitators who do not understand the conditions. So, it is often for the people who receive the assistance, not to renovate the front side of the house, but to renovate other areas of the house. This reflects the miscommunication of various parties in implementing the Bantuan Stimulan Perumahan Swadaya program in Pontianak City. Based on this, it is interesting to know more about how the collaborative pattern of collaboration between these institutions in carrying out their duties and functions to carry out activitiy of Bantuan Stimulan Perumahan Swadaya in Pontianak City. 


\section{Collaboration}

Collaboration is an act of cooperation by positioning each party that cooperates to have an equal position. Cooperation pattern collaboration is usually done to accelerate the work process and aim to overcome resource problems. It is expected that by collaborating the desired goals can be quickly achieved.

One expert in the field of collaboration, Russell M. Linden expressed his opinion on collaboration:

"collaboration occurs when people from different organization (or units within one organization) produce something together through joint effort, resources and decisions making, and share ownership of the final product of productivity. " Linden (2002: 7).

Then a similar opinion was said by David Straus about the nature of a collaborative activity:

"...Collaboration is required at every level of every organization be it a corporation, small business, nonprofit organization, educational institution, government agency, or legislative body. And collaboration takes place not only within these organizations, but also between and among them... They require people to work together to plan, solve problems, and/or make decisions before action can be taken." Straus (2002 : 1-2).

Michel Schrege, whose opinion was cited by Agranoff and Mc Guire, defines collaboration by focusing just on interorganic relations:

"Collaborative management is a concept that describes the process of facilitating and operating in multi organizational arrangements to solve problems than cannot be solved, or solved easily, by single organization. Collaboration is a purposive relationship d designed to solve a problem by creating or discovering a solution within a given set of constrains (e.g., knowledge, time, money, competition, and conventional wisdom." Agranoff dan Mc Guire (2003: 4).

From these various opinions it can be concluded that collaboration is a collaboration carried out by various parties that involves the government and non-government parties, to build or implement a product that can benefit various parties. Donahue and Zeckhauser in their book Collaborative Governance: Private Roles for Public Goals in Turbulent Times stated their thoughts on collaboration, this pattern of cooperation was carried out to increase productivity, to get more information about the knowledge, to strengthen legitimacy, and to overcome the availability of resources. Donahue and Zeckhauser (2011: 63 203)

Russel M. Linden stated that there are several things that must be considered if you want to cooperate with the use of collaboration patterns, the first is to have a basic or knowledge about collaboration, relationships, high stake, constituency for collaboration, and having collaborative leadership. Linden (2002: 59)

\section{Methodology}

This study uses a qualitative method, with a case study approach. This research was conducted using primary data taken directly from the information through key informants related to the research topic. According to Sugiono, Qualitative research method is a research method based on the philosophy of postpositivisme, used to examine the condition of natural objects, (as opposed to experimentation) where the researcher is a key instrument, data source sampling is done by purposive and Snowboal, collecting techniques with triangulation (combined), data analysis is inductive/qualitative, and research results emphasize the meaning rather than generalization. Sugiyono (2016: 15). Furthermore, it was analyzed using interactive methods such as those proposed by Miles and Huberman where research data must go through the stages of data collection processes, data reduction, data presentation, withdrawal of conclusions or verification. Miles and huberman (1992: 20).

\section{Basic of Collaboration}

Basic rules in collaborating are the basis of the collaboration process itself. Linden said five steps to support collaboration. Linden (2002: 73-90). The first characteristic in a basis of collaboration 
is that various members know each other, the purpose of why they are collaborating. The aim must be clearly formulated and understood together. To achieve this goal, a joint effort was made through the division of labor. In this case the executor of Bantuan Stimulan Perumahan Swadaya is Dinas Perumahan Rakyat dan Kawasan Permukiman Kota Pontianak as the institution in charge of implementing the policy and budget manager. Building materials companies act as providers of raw materials to carry out home renovation activities. Then the field facilitator team acts as a super visor in the implementation of Bantuan Stimulan Perumahan Swadaya.

Except knowing the job description, the Bantuan Stimulan Perumahan Swadaya implementers must have a strong will to implement this policy as soon as possible. This means that each member is ready to contribute. The desire to contribute something to achieve collaboration goals. Basically all parties involved in the implementation of Bantuan Stimulan Perumahan Swadaya have a strong desire to carry out their work quickly and accurately. However, it must be admitted that sometimes under certain conditions this cannot be done for various reasons, whether technical reasons such as the slow disbursement of funds for the implementation of Bantuan Stimulan Perumahan Swadaya or nontechnical factors such as weather conditions that do not allow the program implementers to be carried out quickly and precisely in accordance with the predetermined target.

The right people are at the table right people, means the involvement of the right people who are considered to represent stakeholders in an organization and can make agreements and influence others in their group. The obstacles that arise in this stage are that organizations often send people who are not right enough to be less able to influence the sustainability of the collaboration process. In addition, limited human resources also sometimes influence policy implementation. In the implementation of Bantuan Stimulan Perumahan Swadaya, the parties involved in implementing this policy are appropriate. The selection is adjusted to the capabilities, capacities, and capabilities of each implementer. This aims to ensure that Bantuan Stimulan Perumahan Swadaya can be implemented optimally. The parties directly involved in the implementation of the Bantuan Stimulan Perumahan Swadaya in Pontianak City are Dinas Perumahan Rakyat dan Kawasan Pemukiman, Field Facilitator Teams, and Companies or shops that are engaged in building materials and raw material business. Meanwhile, to facilitate the implementation of Bantuan Stimulan Perumahan Rakyat, assistance from external parties is needed, including banking institutions and also Kementerian Perumahan Rakyat dan Kawasan Pemukiman Republik Indonesia,

The parties have open, credible process. It is indicated by the consensus in achieving goals, the existence of basic norms or rules about the behavior of the standards they want to maintain, knowing each other a little patience and openness at the beginning creates credibility later, a transparent work process will build trust that can create success in collaborating. In carrying out the cooperation in implementing Bantuan Stimulan Perumahan Swadaya, each party already has a memorandum of understanding or MoU. In the agreement, there is a division of tasks that must be carried out by each party. Each party must carry out each of their work. If there are parties who do not carry out their work, the implementation of Bantuan Stimulan Perumahan Swadaya will not run properly.

There is champion for the initiative, someone with credibility and clout who makes this high priority. There is someone or other party who can be used as a role model who is able to show interest and effort in collaborating. In the implementation of Bantuan Stimulan Perumahan Swadaya, Pontianak City Government does not have a party that is used as a role model and as a reference for the application of policy. The parties tasked with implementing Bantuan Stimulan Perumahan Swadaya only adhere to the Peraturan Menteri Pekerjaan Umum dan Perumahan Rakyat Republik Indonesia Nomor 13/PRT/M/2016 tentang Bantuan Stimulan Perumahan Swadaya.

\section{Relationship}

Relationship is the glue in the collaboration process. Linden (2002: 94). conducted a study of 130 companies to examine the main causes of collaboration failure. The results of his research showed that $64 \%$ of failures were caused by poor relationships among various participants. Without a strong relationship, there is no trust, and without trust, there will be no collaboration.

Linden presents eight stages in a relationship. Linden (2002: 91-105). Begin meetings with a simple way to check in and get people reconnected. The presence of regular meetings will provide an opportunity for various members to interact and feel connected, so that various members sit together to 
know their common goals and share their contributions in achieving these goals. In the implementation of Bantuan Stimulan Perumahan Swadaya activity, the implementers meet to formulate everything. But this meeting rarely presents all parties involved in implementing this policy. The party who often becomes the initiator in this case is Dinas Perumahan Rakyat dan Kawasan Pemukiman of Pontianak City. While the team of facilitators and companies providing building material services have never been initiators of meetings or conferences. They would rather meet on the ground at the location where the Bantuan Stimulan Perumahan Swadaya policy was made. The reason is that when meetings are held in the field, everything related to evaluation can be solved immediately and on target. But, if the meeting is held in a location far from where the policy is implemented, it is feared that the meeting will only apply formally.

Model open, candid communications; use self-disclousure. The principle is to give other people opportunity to argue, for example by providing opportunities for others because of how to inflame it. Every party that contribute in the Bantuan Stimulan Perumahan Swadaya provides an opportunity to express their opinions openly, both formally and informally. This is done to make the atmosphere of cooperation become conducive from all parties. Usually, communication is done by talking face to face, using social media technology and cellular phones. Including internal parties, external parties and given to express his opinion on the creation of Bantuan Stimulan Perumahan Swadaya. The community implementing provided a forum for what was intended for them to express their opinions about the creation of Bantuan Stimulan Perumahan Swadaya.

Build trust by giving the parties a chance to be accountable. Providing opportunities for various members to be involved in doing things both in terms of supervision, autonomy and flexibility. For this matter the implementing party of Bantuan Stimulan Perumahan Swadaya does not give too much freedom to all parties in conducting supervision because each party has been given a clear job description and in accordance with their respective fields of expertise. But each implementing party is given flexibility in working. As long as they can finish the work on time. However, because of the flexibility of freedom is given, sometimes there are certain parties who cannot complete their assigned tasks on time.

Do some informal exploring and careful listening. When the parties involved interact with each other in a meeting, then they should not only discuss their goals and achievement strategies, but also discuss the expectations of others in their efforts to achieve these goals. The ability of various members to hear the needs of others will help them to meet their needs. Every meeting conducted by the Bantuan Stimulan Perumahan Swadaya implementer, they always discussed matters relating to the problem of Bantuan Stimulan Perumahan Swadaya and beyond the scope of the job description at that time. Like discussing environmental developments in Pontianak City, discussing the urban planing in Pontianak City, and discussing the continuation of the implementation of Bantuan Stimulan Perumahan Swadaya in the following year. Because at this time 2040 houses are not habitable in the Pontianak City, and only around 548 houses were given stimulant assistance. So, there are around 1492 housing units that require help from stimulant assistance, so that Pontianak City does not have the status of a city with the existence of an uninhabitable house.

To make the atmosphere of cooperation more conducive, it is not uncommon for Bantuan Stimulan Perumahan Swadaya implementers to share accurate information, both requested and unrequested. Sharing accurate information, both requested and unsolicited, however this information is deemed necessary in achieving the common goal for the smooth implementation of Bantuan Stimulan Perumahan Swadaya. Then also make conscious use of stories, share experiences by using story media to communicate important information in order to build a relationship, whether it is about the implementation of activities related to Bantuan Stimulan Perumahan Swadaya, or beyond. Set aside time to work explicitly on relationship and trust. There is an informal relationship in order to build a relationship and trust through informal meetings or team building sessions. This informal relationship was built to eliminate negative stigma against the flow of bureaucracy in government. Because what is invited to cooperate is a party that is outside the government zone. So, it is important to build a comfort zone between one party and the other. This is done to build relationships so that they can become more widespread. 
There is an assumption that to build cooperation to be better and more cohesive, it is necessary to find ways to create a sense of an "entity", there is a way to build a unity, whether through a logo, brand, or a particular theme that can fuse a person's attitude. from "me" or "they" to "us". But in the implementation of Bantuan Stimulan Perumahan Swadaya, the implementing members did not make a brand or logo to strengthen the cooperative relationship. It was not done because the form of cooperation carried out in the field of scope that was not too large, was still in one area of Pontianak City coverage and was the policy of Kementerian Pekerjaan Umum dan Perumahan Rakyat Republik Indonesia which was tried to be implemented by the Pontianak City Government. It will be different case if this collaboration involves various types of parties consisting of different country backgrounds. Maybe the use of logos, slogans or brands in strengthening cooperation is needed to strengthen unity among fellow executives.

\section{High Stake}

Linden proposed several steps in realizing commitment in the process of cooperation in collaboration. Linden (2002: 106-125). There are four things that must be done, the first is help others develop a line of slight. The people involved must be able to see the relationship between what they are doing and the greater purpose or impact on others. The purpose of implementing Bantuan Stimulan Perumahan Swadaya is to increase the initiative of low-income societies in the development / improvement of the houses quality and their infrastructure, facilities and utilities. The aim of Bantuan Stimulan Perumahan Swadaya activity is to build livable houses by low-income societies supported by infrastructure, facilities and public utilities so as to make healthy, safe, harmonious and regular and sustainable housing, which has been regulated in the Peraturan Menteri Pekerjaan Umum dan Perumahan Rakyat Republik Indonesia Nomor 13/PRT/ M/2016 tentang Bantuan Stimulan Perumahan Swadaya. Because this is a stimulant aid, the Pontianak City Government provided assistance of Rp.15,000,000, - in the form of building materials to the Pontianak City's people who were selected as recipients of assistance. Later, with this assistance, the societies can renovate the front part of their house that is not feasible to be feasible. It is hoped that in the future if the front part of their house is suitable for habitation, it will motivate them to renovate the other parts that become part of their homes with the funds and materials they get themselves.

Develop a sense of urgency, build priorities in their work through work targets to motivate themselves in completing their work in achieving common goals. Every work in the implementation of Bantuan Stimulan Perumahan Swadaya follows the standard operating procedure instrument. The existence of procedures manage the activities of Bantuan Stimulan Perumahan Swadaya contained in the Peraturan Menteri Pekerjaan Umum dan Perumahan Rakyat Republik Indonesia Nomor 13/PRT/M/2016 tentang Bantuan Stimulan Perumahan Swadaya.

The steps in submitting Bantuan Stimulan Perumahan Swadaya make the submission of names of prospective recipients of Bantuan Stimulan Perumahan Swadaya based on the results of field monitoring assisted by head of neighborhood and head of hamlet, then the data is positioned to the Dinas Perumahan Rakyat dan Kawasan Pemukiman of Pontianak City and made Decree on the determination of the names that have been grouped based on the sub-districts and districts in Pontianak City, after that, the data is sent to the Kementerian Pekerjaan Umum dan Perumahan Rakyat, then from the Kementerian Pekerjaan Umum dan Perumahan Rakyat establishes the locations that will be assisted by issue a decree by name by address, then the data names are verified again by the Dinas Perumahan Rakyat dan Kawasan Permukiman of Pontianak City and assisted by the Field Facilitator Team (TFL) to see the suitability of the data with the results obtained in the field, if the recipient is suitable with the data received, the recipient is determined as a permanent recipient of Bantuan Stimulan Perumahan Swadaya to complete other administrative files. The existence of a accountability report as a form of proof to the Kementerian Pekerjaan Umum dan Perumahan Rakyat that the Bantuan Stimulan Perumahan Swadaya activitiy is in accordance with the Standard Operating Procedure (SOP) which contains attachments to the required documents, photo evidence of housing conditions from $0 \%-30 \%$ for the first stage and $30 \%-100 \%$ for the second stage, as well as other administrative evidence.

Based on operational standard procedures of the Bantuan Stimulan Perumahan Swadaya can be explained about the implementation stage, which first establishes the budget allocation for Bantuan Stimulan Perumahan Swadaya activities for each regency/city compiled by the Kementerian Pekerjaan 
Umum dan Perumahan Rakyat with a period of 60 days and issues of allocation notification, then receives the budget allocation for Bantuan Stimulan Perumahan Swadaya activity to the Mayor of Pontianak with a period of 30 days and issuing a notice of allocation, Dinas Perumahan Rakyat dan Kawasan Permukiman of Pontianak City compiled and submitted a proposal to the Mayor of Pontianak for 4 days long, and then the Mayor of Pontianak submitted the proposal to Kementerian Pekerjaan Umum dan Perumahan Rakyat in the form of a letter of application from low-income people who deserve to receive Bantuan Stimulan Perumahan Rakyat, a statement and power over material, certified photocopy land title or land control certificate from the sub-district head, photocopy of identity card and family card, income statement. The complete file must be completed within 3 days. Then Kementerian Pekerjaan Umum dan Perumahan Rakyat verified the proposal for 30 days to see the completeness of the administration, then the ministry issued a decree in which the letter was issued no later than 15 days after the recipient of the Bantuan Stimulan Perumahan Swadaya was legally stipulated, after a letter from the ministry provided, a Technical Team will be formed, which later the technical team will recruit the Field Facilitator Team and establish a building store or company engaged in the sale of building materials according to the proposal from the Field Facilitator Team, the Field Facilitator Team provides guidance to the people who receive Bantuan Stimulan Perumahan Swadaya, then the Bank appointed as the Pontianak City Government partner will issue a savings book on behalf of each recipient of Bantuan Stimulan Perumahan Swadaya accompanied by the Field Facilitator Team with bring the account opening form; customer identification card; photocopy of decision letter on the determination of the recipient of Bantuan Stimulan Perumahan Swadaya, then the recipient of Bantulan Stimulan Perumahan Swadaya buy materials to the building store accompanied by the Field Facilitator Team carrying a national identity card; photocopy of decision letter on the determination of the recipient of Bantuan Stimulan Perumahan Swadaya; the withdrawal slip of the funds that has been signed, then the recipient has been able to do the house construction supervised by the Field Facilitator Team and also Dinas Perumahan Rakyat dan Kawasan Permukiman of Pontianak City for 120 days for the whole stage, then the Field Facilitator Team makes an activity report that will be sent to the Ministry of Pekerjaan Umum dan Perumahan Rakyat to see the progress.

But in reality, even though the implementing party has been given 120 days, there are still some cases of Bantuan Stimulan Perumahan Swadaya that cannot be completed on time. This usually occurs due to non-technical disturbances such as weather disturbances, which hamper the execution of work. Bantuan Stimulan Perumahan Swadaya is an activity to renovate the front of low-income residents' houses in Pontianak City which are considered slum by the Pontianak City government. In doing renovation, it is necessary to provide conducive weather assistance so that activity can be carried out properly. However, if the weather conditions are less supportive, then the implementation of the activity will be slightly delayed. If the delay of the work lasts a long time, it will cause the work not to be completed according to the target set. In addition to non-technical disruptions, during the implementation of the Bantuan Stimulan Perumahan Swadaya there were also technical problems, the majority of which was caused by the field facilitator team lacking compliance with standard operating procedures in the execution of tasks. But the number of violations that occur is still small. But even so, it will still interfere with the performance of other parties who participated in collaborating in the implementation of Bantuan Stimulan Perumahan Swadaya activity in Pontianak City.

Make current performance visible and accountability real. Making a clear performance measure will make various members responsible for achieving the desired results. The implementation of Bantuan Stimulan Perumahan Swadaya is divided into two stages, that is the first and the second stages. In the first stage, people who have received this assistance are given $50 \%$ of the funds that have been set up to buy the needs of building materials, and after $30 \%$ physical progress is completed, the second phase of disbursement is completed. The disbursement of funds carried out in as many as two stages serves to control the recipient so that the funds that have been given are in accordance with the needs. If the first stage is not done, then the responsibility of the beneficiary group cannot do the second phase of disbursement until all beneficiary groups complete the first phase with $30 \%$ physical progress. With the division of two stages in the construction of a house, it can manage the time and make it easier to supervise directly so that if there is an obstacle at the time of work, then the action can be done to solve 
it. Each recipient of Bantuan Stimulan Perumahan Swadaya must make the recipient group as many as 20 (twenty) people based on the Peraturan Menteri Pekerjaan Umum dan Perumahan Rakyat Republik Indonesia Nomor 13/PRT/M/2016 pasal 13 ayat (1) huruf g,"Bersedia membentuk kelompok.' dan ayat (3),"Kelompok paling banyak 20 (dua puluh) orang." The purpose and aim of the aid formation recipient groups is to facilitate the administration of books and also the establishment of cooperation between beneficiaries.

Identify a higher purpose. This is one way to create commitment and trust among various members. By trying to identify the larger goals that can be generated from the collaborative efforts they do, for example it is humanity purpose, the part of collaborative effort they are currently doing will have an impact on the lives of others in the future. After all the implementation activities of Bantuan Stimulan Perumahan Swadaya were completed, the implementers evaluated the results of their performance so far. The purpose of this evaluation is to find out the obstacles faced during the implementation of the activities, as well as to report on the accountability of the implementation activities. Thus if it will be used as input for the implementation of Bantuan Stimulan Perumahan Swadaya in the following years.

\section{Constituency for Collaboration}

Linden argues that maintaining collaboration also creates constituency. This requires political influence or strategy to encourage various stakeholders to continue to be in the collaboration process. Linden stated six stages in creating constituency for collaboration. Linden (2002: 127-144). Create visible signs of success and share credit widely. One form of motivating various participants is to reward their success both in material and non-material terms, and to share their achievements with others, so that they are motivated to do the same. However, in the implementation of Bantuan Stimulan Perumahan Swadaya, there is no reward and punishment given to parties involved in implementing the policy. Maybe in the future this will be applied.

Set clear, simple goals that resonate with public; invite outside groups to help and monitor progress. There is public involvement to help oversee the implementation of collaboration. For the issue of supervision in the implementation of Bantuan Stimulan Perumahan Swadaya, all of them are the responsibility of the field facilitator team and Dinas Perumahan Rakyat dan Kawasan Permukiman. The general public/people is not given authority to supervise. Use symbols to reinforce the partnership's power. In collaborating, sometimes a symbol is needed which signifies a joint effort in carrying out certain goals. In implementing Bantuan Stimulan Perumahan Swadaya there are no specific symbols or terms used as a form of encouragement for the implementers to implement Bantuan Stimulan Perumahan Swadaya, because the scope of policy implementation is not too broad, it is not needed at this time.

Involve stakeholders at every step, by involving stakeholders in each implementation, will make various stakeholders feel valued for the contribution they make. In implementing Bantuan Stimulan Perumahan Swadaya, the stakeholders involved are not too many, it may only involve the heads of neighbourhood and the head of hamlet only, their involvement is limited to providing information to the government about where the low-income societies are eligible and deserve to get Bantuan Stimulan Perumahan Swadaya. Moreover, policy implementers can implement the policy independently.

Educate stakeholders to see the connection between collaboration and their self-interest. To increase the involvement of various stakeholders, it is necessary to be knowledgeable about the relationship between collaboration and the benefits they get from the collaboration itself. In the implementation of Bantuan Stimulan Perumahan Swadaya, the implementers of the Bantuan Stimulan Perumahan Swadaya activities were never given the knowledge in the form of training on collaborating or cooperating. The only training that has ever been given is only training on how to carry out the implementation of Bantuan Stimulan Perumahan Swadaya that is good and true, in accordance with the standard operating procedures that apply. Think politically, without becoming political collaborative efforts can be undone quickly by political forces. Sometimes in a partnership there are only parties who are not productive. In dealing with counterproductive members, political approaches such as coercion will be more effective so that various participants remain in the right rules and show good results. In 
the case of Bantuan Stimulan Perumahan Swadaya a political and familial approach is carried out if one of the team members collaborates to implement Bantuan Stimulan Perumahan Swadaya to experience counter productive problems. However, the incident was very rare. During the implementation of Bantuan Stimulan Perumahan Swadaya in 2017, there were only one or two counter productive cases. However, after the problem is resolved, the work that should be carried out in accordance with the standard operating procedures is immediately implemented again.

\section{Collaborative Leadership}

Leadership is something that cannot be separated from the side of human life, whether in social life, organization or state. Leaders have a vital role in carrying out activities. Leaders can direct their members to success. In collaboration, the leader also gets an important role in the process of successful implementation activities. Linden proposed four stages in collaborative leadership. Linden (2002: 145166).

Resolute and driven-especialy about collaboration. Firm and able to encourage their staff to collaborate. These criteria are needed in the implementation of collaboration. When illustrated the leader in this collaboration is the same as the role of the captain on a sports team. He is not in a higher position and also lower than the other members. But he has the right to regulate the stability of on going activities. In the implementation of Bantuan Stimulan Perumahan Swadaya, the role of the leader was taken by the Head of Dinas Perumahan Rakyat dan Kawasan Permukiman of Pontiank City. The leader functions as a mediator if one of the implementing agencies of the policy does not work in accordance with its main duties and functions. Besides that, the leader also acted as the person in charge of the implementation of Bantuan Stimulan Perumahan Swadaya Activities in Pontianak City. Modest-a strong but measured ego. On the one hand leadership in collaboration must be firm, but on the other hand it must be simple and able to control its ego and even tend to be humble. The role of the leader in implementing Bantuan Stimulan Perumahan Swadaya does not take too much care of the ego or the discipline of the institution in carrying out its duties. Because basically the leader gives the implementers flexibility in working, the most important thing is that the implementing members can complete the work on time and in accordance with the standards that had been set.

Inclusive-uses "pull" much more than "push". Push is closely related to commands that leaders can do to their staff, this approach is sometimes needed in collaboration, but in collaboration sometimes involves members of other organizations in authority. Then pull will give them time and space to decide to be involved in collaboration on the basis of their own will. This condition will cause commitment among them. In implementing Bantuan Stimulan Perumahan Swadaya, the leader's role is not too visible in inclusive-uses "pull" much more than "push". Because the scope of work for the implementation Bantuan Stimulan Perumahan Swadaya is not too broad and supported by the members involved in the implementation of policies as well as professionals in their master fields. So far in the implementation of Bantuan Stimulan Perumahan Swadaya in 2017, it can run smoothly without much interference from leaders. The work is carried out by auto pilot based on standard operating procedures.

Collaborative mind set-sees connections to something larger. A leader in collaborating must be able to think ahead by seeing the possibility of working with something bigger. Bantuan Stimulan Perumahan Swadaya Policy is an activity that plays a role in providing stimulants to low-income families in building their house. This policy is implicitly a fiscary policy. Thus, so that the policy can motivate people, we must have a visionary leader who has a long standing plan to improve the level of happiness of the society through the implementation of Bantuan Stimulan Perumahan Swadaya activity. So far, the leaders and the implementing members of Bantuan Stimulan Perumahan Swadaya activities have visionary character. This can be seen from their attitude and seriousness at work, and also the high enthusiasm in accepting this policy. If the implementers and those who receive the benefits support each other, it will indirectly make the implementation of Bantuan Stimulan Perumahan Swadaya activity easier to implement.

\section{Conclusion}


In collaborative implementation of Bantuan Stimulan Perumahan Swadaya, basically it has been successfully carried out well. But the collaboration has not been fully carried out cohesively. The less cohesive of collaboration cause some obstacles in the implementation of Bantuan Stimulan Perumahan Swadaya activities. This obstacle occurs because of non-technical factors that cannot be predicted for their existence such as weather disturbances so that the implementation of Bantuan Stimulan Perumahan Swadaya activities cannot be carried out according to standard operating procedures. In addition, the lack of cohesiveness in collaboration was also due to the lack of compactness of the field facilitator team in working with other institutions involved in the implementation of Bantuan Stimulan Perumahan Swadaya. However, the percentage of number can still be tolerated, meaning that it is still in the small category. In order to make the implementation of Bantuan Stimulan Perumahan Swadaya in Pontianak City in the future, the next have to find a solution to all the problems that occur at this time, so that the collaboration can be done well and cohesively.

\section{Reference}

Agranoff, Robert. dan Michal, Mc Guire. 2003. Collaborative Public Management New Strategies for Local Governments. Washington, D.C.: Georgetown University Press.

Creswell, John W. 2012. (edisi ketiga). Research Design; Pendekatan Kualitatif, Kuantitatif dan Mixed.Yogyakarta: Pustaka Pelajar.

Donahue, Jhon. dan Richard, Zeckhauser. 2011. Collaborative Governance: Private Roles for Public Goals in Turbulent Times. New Jersey: Princeton University Press.

Linden, Russell M. 2002. Working Across Boundaries: Making Collaboration, Work in Government and Nonprofit Organization. San Fransisco: Jossey-Bass.

Marshal, E. M. 1995. Transforming The Way We Work: The Power of Collaborative Workplace. New York: American Management Association.

Miles, Matthew B. dan A. Michael Huberman. 1992. Analisis Data Kualitatif; Buku Sumber tentang Metode-Metode Baru. Terjemahan Tjetjep Rodendi Rohidi. Jakarta: Universitas Indonesia Press.

Sabaruddin, Abdul. 2015. Manajemen Kolaborasi Dalam Pelayanan Publik Teori, Konsep dan Aplikasi. Yogyakarta: Graha Ilmu.

Straus, David. 2002. How to Make Collaboration Work. San Fransisco: Berrett Koehler Publisher.

Sugiyono. 2010. Metode Penelitian Pendidikan. Bandung: Alfabeta.

Sugiyono. 2016. Metode Penelitian Pendidikan Pendekatan Kuantitatif Kualitatif dan R\&D. Bandung: Alfabeta. 